\title{
Risk Assessment of Health of Employees of Titanium-Magnetic Production
}

\author{
Vlasov EM*1, Ustinova $\mathrm{OY}^{1}$, Shlyapnikov $\mathrm{DM}^{2}$ and Vorobeva $\mathrm{AA}^{1}$ \\ ${ }^{1}$ FBUN Federal Research Center for Medical and Preventive Health Risk Management Technologies for the Population, Russia \\ ${ }^{2}$ Management of the Federal Service for Supervision of Consumer Rights Protection and Human Welfare in the Perm Territory, Russia
}

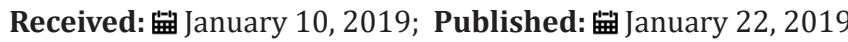

*Corresponding author: Vlasov EM, FBUN Federal Research Center for Medical and Preventive Health Risk Management Technologies for the Population, Russia

Abbreviations: RF: Russian Federation; RR: Relative Risk; EF: Etiological Share; CI: Confidence Interval; AH: Arterial Hypertension

\section{Min Review}

Under real production conditions, workers are affected by many production and non-production factors (risk factors) that enhance or weaken the mutual effects. In this case, the factors of the production environment may not exceed the standard values, but in combination with each other lead to adverse effects. The variety of influencing factors and the possibility of their combined effect on the body of workers determines the need for an integrated approach in the development of measures to improve working conditions, prevent occupational and occupational morbidity of workers and reduction of occupational risk. In the conditions of a shortage of labor resources, the social significance of the health of workers and measures for their protection increases. Preservation of occupational health, occupational longevity is possible with the introduction of advanced technologies of preserving health [1]. One of the priorities of the state demographic policy in the Russian Federation (RF) for the period up to 2025 is determined to preserve and strengthen the health of the population, increase the role of disease prevention and the formation of a healthy lifestyle [2].

The goal is to analyze the health status of workers in titaniummagnesium production to substantiate measures to minimize occupational risk. Materials and methods. Surveillance group - 103 workers exposed to a complex of production factors. The professional composition of the workers is represented by the following main specialties: crusher, gas-trap dust maintenance operator, smelter, non-ferrous metals and alloys spreader, chlorinator, chlorine conductor, molten salt electrolysis cell, and grinder. Comparison group - 47 workers (men) performing work outside of professional contact with production factors. The groups are comparable by age, length of service, sex. The average age is $37.36 \pm 1.52$ years, the average length of service is $12.85 \pm 2.30$ years; all men. Information on working conditions (workplace certification cards), the professional route, the results of studies of parameters of production factors at workplaces, information from primary medical records about the presence of somatic diseases and their dynamics were formalized and entered into a single electronic database.

Conducted medical and sociological study of the prevalence of social risk factors, clinical examination, laboratory tests, cardiorespiratory functional screening, statistical and mathematical analysis using the statistical program STATISTICA for Windows 7.0 and using the program module, executed in the form of an MS Excel macro. The critical level of significance when testing statistical hypotheses in the study was assumed to be 0.05 (significance of differences $\mathrm{p}<0.05$ ). Used epidemiological research methods: the calculation of the relative risk (RR) and etiological share (EF). To assess the reliability - 95\% confidence interval (CI). The presence of a connection is considered to be reliably established if the lower limit of the confidence interval is greater than one.

\section{Results and Discussion}

For workers in varying degrees, in accordance with GOST 12.0.003-74 "Occupational safety standards system. Dangerous and harmful production factors. Classification "affects the following groups of dangerous and harmful production factors: physical, chemical and psychophysiological. According to the results of the workplace certification carried out at the enterprise, the working conditions at the workplaces of the monitoring group, in accordance with Guideline P 2.2.2006-05 "Guidelines for the hygienic assessment of factors of the working environment and the work process. Criteria and classification of working conditions ", 
assessed as harmful: class of working conditions 3.1-3.3. An analysis of the results of a medical and sociological study of the prevalence of behavioral risk factors did not reveal intergroup differences. According to the survey results, the following laboratory deviations ( $p<0.05$ ) were identified: hyperglycemia, hypercholesterolemia in combination with an increase in the proatherogenic fraction of LDL cholesterol, an increase in the activity of free radical oxidation processes, antioxidant protection resources, increased hs-CRP.

Evaluation of the vasomotor function of endotheliumdependent vasodilation revealed an insufficient vasodilatation of the brachial artery after performing an occlusive test. Oxidative stress is a risk factor for the implementation of proatherogenic hypercholesterolemia, which indicates the activation of the atherosclerotic process; dysregulation of vascular tone $(p<0.05)$. Observed oxidative stress is observed as a risk factor for the development of endothelial dysfunction [3]. It has been proven that people with high levels of hs-CRP are significantly more likely to develop cardiovascular disease, as evidenced by the high incidence of medical examinations $[4,5]$. The proportion of workers with arterial hypertension $(\mathrm{AH})$ was $33.3 \%$, in the comparison group $17.6 \%, \mathrm{p}<0.05$ (RR 1.99; 95\% CI 1.01-3.93; EF = 47\%; degree of

\section{ISSN: 2574-1241}

DOI: $10.26717 / B J S T R .2019 .13 .002393$

Vlasov EM. Biomed J Sci \& Tech Res

CC $(9)$ This work is licensed under Creative

Submission Link: https://biomedres.us/submit-manuscript.php professional conditionality is average). Periodic determination is traced. The development of autonomic dysfunction syndrome, like hypertension, is more associated with exposure to noise $(\mathrm{F}=$ 613; R2 = 0.88; $\mathrm{p}<0.001$ ). The analysis of the results of the studies made it possible to formulate proposals for the formation of a risk-oriented program for the prevention of health problems for workers in titanium and magnesium production.

\section{References}

1. Izmerov NF, Bukhtiyarov IV, Prokopenko LV, Kostenko NA (2014) The concept of the implementation of the state policy aimed at preserving the health of the working population of Russia for the period up to 2020 and beyond. M LLC SPM-Industry p. 47.

2. (2009) On the National Security Strategy of the Russian Federation until 2020. Decree of the President of the Russian Federation of May $12 \mathrm{p}$. 2-34.

3. Celermajer DS, Sorensen KE, Gooch VM, Spiegelhalter DJ, Miller OI, (1992) Non-invasive detection of endothelial dysfunction in children and adults at risk of atherosclerosis. Lancet 340(8828): 1111-1115.

4. Li YP, Mold C, Du Clos TW (1994) Sublytic complement of the attack and C-reactive protein binding sites on the cell membranes. Journal of immunology 152(6): 2995-3005.

5. Pepys MB, Hirschfield GM (2001) C-reactive protein and atherothrombosis. Italian heart of cardiology 2(3): 196-199.

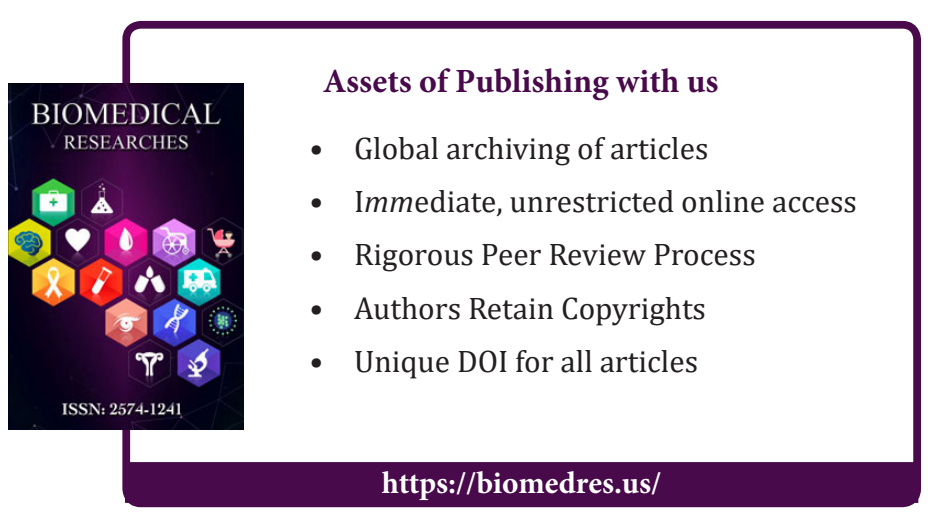

